Meta

Journal des traducteurs

Translators' Journal

\title{
Has Globalisation Unburdened the Translator?
}

\section{Karen Korning Zethsen}

Volume 55, numéro 3, septembre 2010

URI : https://id.erudit.org/iderudit/045076ar

DOI : https://doi.org/10.7202/045076ar

Aller au sommaire du numéro

\section{Éditeur(s)}

Les Presses de l'Université de Montréal

ISSN

0026-0452 (imprimé)

1492-1421 (numérique)

Découvrir la revue

Citer cet article

Zethsen, K. K. (2010). Has Globalisation Unburdened the Translator? Meta, 55(3), 545-557. https://doi.org/10.7202/045076ar

\section{Résumé de l'article}

Maintenant que le terme mondialisation s'est banalisé, il est naturel de se demander si la tâche du traducteur s'est simplifiée. Comme de plus en plus de gens partout dans le monde acquièrent les mêmes produits, regardent les mêmes films américains et écoutent la même musique, on a tendance à penser qu'ils ont recours au même cadre de référence et qu'ils partagent une même culture, une cultura franca. Si c'est le cas, la traduction devrait s'en trouver simplifiée, les concepts culturels ayant $a$ priori un terme correspondant dans chaque langue. Prétendre qu'il n'y a pas de culture globale serait insensé, mais il est parfaitement raisonnable de se demander si elle est la seule culture ou si elle ne constitue qu'un fragment de la culture de référence d'une personne. Le présent article vise à discuter et à définir le concept de cultura franca et à examiner si la mondialisation, de fait, facilite la tâche du traducteur.
Ce document est protégé par la loi sur le droit d'auteur. L'utilisation des services d'Érudit (y compris la reproduction) est assujettie à sa politique d'utilisation que vous pouvez consulter en ligne.

https://apropos.erudit.org/fr/usagers/politique-dutilisation/ 


\title{
Has Globalisation Unburdened the Translator?
}

\author{
KAREN KORNING ZETHSEN \\ Aarhus School of Business, Aarhus, Denmark \\ kkz@asb.dk
}

\begin{abstract}
RÉSUMÉ
Maintenant que le terme mondialisation s'est banalisé, il est naturel de se demander si la tâche du traducteur s'est simplifiée. Comme de plus en plus de gens partout dans le monde acquièrent les mêmes produits, regardent les mêmes films américains et écoutent la même musique, on a tendance à penser qu'ils ont recours au même cadre de référence et qu'ils partagent une même culture, une cultura franca. Si c'est le cas, la traduction devrait s'en trouver simplifiée, les concepts culturels ayant a priori un terme correspondant dans chaque langue. Prétendre qu'il n'y a pas de culture globale serait insensé, mais il est parfaitement raisonnable de se demander si elle est la seule culture ou si elle ne constitue qu'un fragment de la culture de référence d'une personne. Le présent article vise à discuter et à définir le concept de cultura franca et à examiner si la mondialisation, de fait, facilite la tâche du traducteur.
\end{abstract}

\begin{abstract}
In an age where globalisation has become an everyday word it is quite natural to assume that the task of the translator has become much less complicated. As people around the globe increasingly buy the same standardised products, are entertained by the same American films and listen to the same music, it is often taken for granted that generally they have the same frame of reference, that they share a cultura franca. If this is so, translation should indeed be more straightforward as cultural concepts will have a ready name in each language. It would be nonsensical to argue that no global culture exists, but it seems relevant to ask whether the global culture is the only culture or whether it is only a fragment of the cultural framework of a person. This article aims at discussing and defining the concept of cultura franca and whether globalisation has in fact unburdened the translator.
\end{abstract}

\section{MOTS CLÉS/KEYWORDS}

mondialisation, cultura franca, cultures nationales, médiation culturelle, traduction spécialisée

globalisation, cultura franca, national culture, cultural mediation, specialised translation

\section{Introduction - the translator as cultural mediator}

The role of the language for specific purposes (LSP) translator in the business community does in many ways go unnoticed and unacknowledged - the translator is seen as someone carrying out a fairly automatic low-status function (Dam and Zethsen 2008; 2009; forthcoming). Within translation studies, scholars are of course aware of what it takes to be a good translator and this knowledge leads to a different image of the translator and the many-faceted challenges he faces. With the skopos theory, Reiss and Vermeer (1984) tried to enhance the status of the practising translator by claiming a more active role for the translator in the communication process. They see the translator as an expert who is responsible for obtaining information about the skopos (purpose) of the translation and for translating in accordance with

Meta LV, 3, 2010 
it, even if the translated text, in order to fulfill the communicative purpose, would be very different from the original one (Vermeer 1989, cited in Venuti 2000). Within LSP translation studies it is now considered the obligation of the translator to do his utmost to understand what the purpose of the communication is, who the parties involved are and how best to transfer the intended messages. In real life, the translator should no longer be perceived as a walking dictionary, but should rather be considered as a cultural mediator (Katan 1999). That is, translation is taken one step further - ideally the translator should no longer be invisible, but should participate actively in the communication process. According to Katan (1999: 16), the term cultural mediator was first introduced in Stephen Bochner's (1981) The Mediating Person and Cultural Identity, and Taft (cited in Katan 1999: 12) defines the term as follows: "[a] cultural mediator is a person who facilitates communication, understanding, and action between persons or groups who differ with respect to language and culture." Venuti (2000: 5) also sees translation as mediation. Speaking about the relative autonomy of translation, the textual features and operations or strategies that distinguish it from the foreign text and from texts genuinely written in the translating language, he concludes that " $t$ ] hese complicated features and strategies are what prevent translating from being unmediated or transparent communication" (our emphasis). But in the age of globalisation, does it still make sense to talk about cultural differences, which need to be translated or mediated? In order to answer this question it is relevant to consider the concept of culture.

\section{Definition of culture}

Definitions of culture abound - in 1952 the American anthropologists Kroeber and Kluckhohn collected and systematised all the definitions of culture available at the time. They ended up with no less than 164 definitions (Askehave and Norlyk 2006: 7 ) and in all likelihood this number has vastly increased. For the general audience, there is a tendency to associate culture with high culture, i.e., art, music, literature etc., while specialists such as Edward Tylor's (an English anthropologist from the $19^{\text {th }}$ century) make use of more sophisticated definitions. Tylor's much quoted definition of culture came out as early as 1871: "Culture or civilization, taken in its wide ethnographic sense, is that complex whole which includes knowledge, belief, art, morals, law, custom and any other capabilities and habits acquired by man as a member of society." For a general definition this still seems valid (and is commendably short!). Tylor's definition is not limited to high culture, but includes customs, habits, etc.

It is taken for granted that culture (probably most often in a sense leaning towards high culture, as is common in language teaching [Alptekin 2002: 59]) represents a considerable challenge for the literary translator, but less so for the LSP translator. Although culture in any form is often seen as very dominant in literature, it is far from irrelevant in LSP translation. It may be argued that, potentially, culture may be equally relevant in all genres, but that different kinds of culture are involved. In the context of LSP translation, a very broad understanding and definition of the concept of culture is needed, to be used both theoretically and practically. Within the field of translation studies, Vermeer (1992: 38) defines culture as "the whole of norms and conventions governing social behaviour and its results.” Like Tylor's, Vermeer's definition is quite abstract, while Nedergaard-Larsen (1993: 211) sums up 
the culture-bound areas potentially problematic to the translator. Her list (shown below in a slightly shortened version) is far from being exhaustive, as she herself points out, but is a good reminder of the wide range of areas relevant to the concept of culture in a broad sense:

- geography (mountains, rivers);

- meteorology (weather, climate);

- biology (flora, fauna);

- cultural geography (regions, towns, roads, streets);

- buildings (monuments, castles, etc.);

- events (wars, revolutions, flag days);

- people (well-known historical persons);

- industrial level (trade and industry, energy supply, etc.);

- social organisation (defence, judicial system, police, prisons, local and central authorities);

- politics (state management, ministries, electoral system, political parties, etc.);

- social conditions (groups, subcultures, living conditions, problems);

- ways of life, customs (housing, transport, food, meals, clothing, family relations, etc.);

- religion (churches, rituals, morals, ministers, religious holidays, saints, etc.);

- education (schools, colleges, universities, lines of education, exams, etc.);

- media (TV, radio, newspapers, magazines);

- culture [i.e., high culture];

- leisure activities (museums, works of art, literature, authors, actors, sports, etc.).

Defined as such, culture penetrates all areas of life, and therefore cannot be disregarded in any kind of translation.

\section{National culture, discourse communities or cultura franca?}

\subsection{National culture}

The concept of national culture has always played a large role in our general understanding of culture. Cultural myths (Katan 1999: 219-228) and cultural stereotypes are more often than not equated with national culture; the Japanese, the Italians, the Germans, the Americans, etc. behave in a certain way and take a certain view of the world. We cannot dispense with the concept of national culture, but from the point of view of the translator it seems important that his definition of culture not be overshadowed by the rather limited and very superficial concept of national culture - national culture is not insignificant, but is only one parameter among many. Within intercultural management theory, the functionalist approach (Hall 1983/1989; Hofstede 1991/2005) based on national cultural stereotypes has dominated for decades:

To prepare for a multicultural meeting and to prepare for potential communication problems in an intercultural or global context, the business world traditionally relies on the functionalist approach as it offers a structured framework and a set of operative tools that are easily applicable in the practical context of international business (Askehave and Norlyk 2006: 10-11).

The functionalist approach is predictive and thereby practical, but represents a rather simplified view of the world. Within academic circles the functionalist 
approach has, however, been challenged by, for instance, the non-functionalist interpretive approach of Geertz (1973), which is based on anthropological studies. The interpretivists stress the importance of interpretation and context, arguing that each cultural meeting is unique:

For interpretivists, roughly speaking, the most important tool in the meeting of cultures is an open mind, and the willingness constantly to review and adjust one's impressions and interpretations of other cultures, and to avoid cultural stereotypes and ethnocentric value judgments (Askehave and Norlyk 2006: 27).

The interpretivists take a more complex and dynamic view on culture in which people's identity is not only a product of their nationality, but of all the different contexts in which they take part - a view which is highly compatible with the concept of discourse communities and which seems useful in the context of translation.

\subsection{Discourse communities}

The widespread use today of the term discourse community (Swales 1990) reflects a retreat from the view that the concept of culture is limited to a question of national cultures or stereotypes. National cultures exist, but they are only part of a person's cultural make-up. All human beings belong to several different discourse communities and many of these communities exist across borders. If you are a baker by profession you may be able to communicate satisfactorily with a baker from a different culture using very simple communicative means (as long as you stay roughly within your discourse community). In addition to using the same materials you may have the same world experience of burnt bread and early mornings and so on. If you are a mother with young children, a football fan, a musician, a first-time house owner - the list is infinite - then communication across borders may be considerably easier with like-minded people than with people from your own country who do not share your situation, profession or interests (even when this communication has to be by means of a lingua franca). As Kirkness puts it:

Might it be easier for French, German or English linguists or neurosurgeons to exchange information with each other on technical matters without translation than it is for them to communicate with lay people in their own vernacular communities? (Kirkness 1997: 5)

The discourse communities are determined by a great number of factors such as interests, job, race, gender, nationality, and of course language.

\subsection{Has globalisation created a cultura franca?}

In the age of globalisation numerous discourse communities cross borders, including linguistic ones, and in the majority of cases make use of the world's lingua franca: English. In earlier days Latin was of course the lingua franca of the learned Western world. Today it has been replaced by English, which is spoken not only by the privileged few. It is not too complicated to learn to speak basic English and our efforts are supported by the electronic media and by the present day dominance of American culture in particular. As a result many people speak English without much inhibition and it naturally follows that English is used as lingua franca in many business 
contexts (including translation). However, the English spoken by most non-native speakers is not connected to any national culture (English, Australian or American). It is instead a hybrid produced by the many contexts (often media contexts) where the speaker has been exposed to the English language. This raises the question of how to pin down the cultural background of English spoken (or used in translated texts) as a lingua franca. Some form of English is the medium of communication, but does a lingua franca also imply the existence of a so-called cultura franca?

Cultura franca seems a very useful concept and a tempting logical consequence of lingua franca. However, it was impossible to find any definition for it. The only translation scholar (to our knowledge) who uses the concept is Snell-Hornby (1999). Unfortunately she does not define it, but merely mentions it in passing: speaking about English as the international lingua franca, she mentions "our globalised 'McWorld' with its technological 'cultura franca'" (Snell-Hornby 1999: 109, our italics). She later mentions "the levelling of culture-specific differences within the technological 'cultura franca"” (Snell-Hornby 1999: 110), without getting closer to a definition. By modifying cultura franca with technological, Snell-Hornby indicates that, for her, cultura franca is limited to the area of technology. What exactly she means by technological is unclear, but it seems to indicate anything non-literary in relation to translation. In the rest of her article she uses the adjectives supranational and supra-cultural, when speaking about cultures which overrun (or try to overrun) national boundaries (for instance, EU culture). In chapter four of her book (2006), Snell-Hornby more or less resumes this discussion, but without referring to cultura franca.

For the purposes of this article it is useful to establish two definitions of cultura franca:

1. a common culture existing in a discourse community and thereby facilitating communication between members of this community

and by extension from lingua franca:

2. a globalised common culture which transgresses discourse communities and which eliminates the existence of cultural barriers in international communication (including translation).

Besides her technological reference, Snell-Hornby seems to use a second and broader definition for most non-literary (or small cultural) purposes. She describes international English (i.e., as lingua franca) as a free-floating language but observes that today's cultura franca draws heavily on US culture. In other words, US culture is to the cultura franca of the present time what the English language is to English as a lingua franca.

Definition 1 cleary defines cultura franca within the concept of a discourse community, its common culture as background for a shared language within a limited field. But Definition 2 is more problematic. For translation studies it raises questions whether this cultura franca can be so broadly defined to fit our age of globalisation.

Various hypotheses may be advanced to suggest which cultural background speakers of English as lingua franca rely on.

\subsubsection{Hypothesis 1}

Speakers of English (whether native or not) rely on British or US culture. (Speakers also refers to written communication, including translation.) 
One immediately questions this statement since obviously basic English is frequently spoken with very limited knowledge of British or US culture. In fact, most of the communication in English today involves non-native speakers, as only about one fourth of all English speakers in the world are native (Crystal 2003). Alptekin (2002: 61) rhetorically asks "[h]ow relevant, then, are the conventions of British politeness or American informality to the Japanese and Turks, say, when doing business in English?" Surprisingly, however, Hypothesis 1 may be quite widely accepted and in situations of asymmetric (native speaker - non-native speaker), communication the native speaker of English often unconsciously assumes that other speakers of English more or less share their cultural background.

\subsubsection{Hypothesis 2}

English as lingua franca exists as a "free-floating lingua franca" in a-cultural vacuum, implying that the language is used independently of any culture, as explained by SnellHornb and McKay:

[English is]... the free-floating lingua franca ('International English') that has largely lost track of its original cultural identity, its idioms, its hidden connotations, its grammatical subtleties, and has become a reduced standardised form of language for supracultural communication - the McLanguage of our globalised 'McWorld' or the 'Eurospeak' of our multilingual continent (Snell-Hornby 1999: 109)

[...] the language [international English] belongs to no one culture but, rather, provides the basis for promoting cross-cultural understanding in an increasingly global village (McKay 2000: 10).

This seems highly unlikely considering the general consensus about the strong cultural impact on communication in general. It seems untenable to separate the language someone uses from his culture, especially since large parts of a person's cultural background are unconscious.

\subsubsection{Hypothesis 3}

Speakers of English as lingua franca make use of a supranational culture, the cultura franca of the global village (probably based on a U.S. / western common culture) transgressing discourse communities. Alptekin (2002: 62) distinguishes teaching a foreign language (where the language cannot be separated from culture) from teaching an international language, "whose culture becomes the world itself."

The expression global village is so fashionable that it is easy to conclude that the phenomenon does in fact exist. But nowadays do people live in a global village with roughly the same cultural framework or would it be more realistic to adopt a concept of discourse communities? Could it be that expressions such as global village and cultura franca are too superficial and give us a false sense of globalisation? It is certainly true that among young people, various supranational subcultures (sports, music, fashion) exist which readily generate a kind of transnational communication. But this cannot be generalized and there may be other life areas where the national, family or educational backgrounds prevail. Perhaps the global village is only a few large discourse communities operating within limited parts of the cultural framework. A more complex grid may be necessary to determine the cultural background of a target group. 


\subsubsection{Hypothesis 4}

To a certain extent, speakers of English as lingua franca rely on a cultura franca, but they generally use the lingua franca on top of their own cultural backgrounds which may be highly variable.

This is the most plausible hypothesis. If true, this would explain why intercultural communication is so prone to misunderstanding; the language used (English) may imply a specific cultural background which is absent - it is easy to assume that if you technically understand each other (through word denotation), then you also share the same connotations, concepts of politeness, world view, experiences, etc. The global village concept does not seem to take into consideration the many factors on which the cultural background of a person is based (as listed by Nedergaard-Larsen 1993), but merely represents a kind of surface culture.

The above discussion was focused on the relationship between English as a lingua franca and the concept of cultura franca. Now, what is the role of translation? Evidently most translations today are done from or into English. This means that the field of translation also accords English the status of a lingua franca in the sense that very often the receiver of the target text or the writer of a particular source text are not native English speakers. Consequently, the question of whether a lingua franca also implies a cultura franca is highly relevant for translation.

So far most discussions on the importance of culture in translation have been based on literary translation. A number of scholars analyse literary texts and their specific cultural challenges (numerous examples in Venuti 2000) while others examine the cultural role of translation in society (Bassnett and Lefevere 1990). For many literary translation scholars, the translator is not only a mediator but an active conveyor of culture and ideology (e.g., Tymoczko 2003). Many insights from literary translation studies are, of course, relevant for the study of LSP translation, but there appears to be a lack of empirical studies dealing with the role of culture in day-to-day translation, i.e., translation as part of business communication. The nature of cultural problems in LSP translation may be more subtle than for literary translation, but they exist nonetheless. It is always easy to find examples of certain types of technical texts with very few intercultural problems, and the existence of such texts clearly supports the view that globalisation facilitates the LSP translator's work. This is the gist of Snell-Hornby (1999) whose distinction between global and culture-specific seems to be a distinction between LSP and literary translation. The language of literary texts is "the exact opposite of the globalised supra-cultural 'McLanguage' for online fast consumption" (Snell-Hornby 1999: 117). However, these technical texts are just one end of a wide LSP range and the following case is intended to show that culturebound challenges, also to the business translator, are still very much around - even in the age of globalisation.

\section{The Thorntons case}

Companies may well target their business-to-business communication to international colleagues whom they believe to be members of the global village. But is the global village a realistic concept in practice? Does it unburden the LSP translator and 
free him from cultural worries when translating? Our hypothesis is that it does not and that cultural elements potentially presenting culture-based translational problems will always exist. To verify this hypothesis, a number of illustrative analyses have been carried out on translations of a text belonging to what is presumed to be a typical globalised area - retailing. Nine experienced translators (an average of 10 years experience) were asked to translate a letter from the English chocolate manufacturer Thorntons and comment on their translation. The letter contains a number of words and expressions pertaining to the semantic field of retail shopping and these will be our focus here. The data obtained in this case were originally used to exemplify the many different microstrategies used in connection with the translation of culturally-bound words and expressions (Zethsen 2006). In this context, however, the aim was to study the extent to which these seemingly globalised words are rooted in the English (or Anglo-American) culture. The text to be translated was an authentic text, though it was not originally part of a letter, but taken from Thorntons' website under franchise opportunities. As Thorntons operates only in Great Britain, a fictive situation in which Thorntons would decide to move into the Scandinavian market was invented. The strategy would be to start with Denmark and have their sales manager write a letter to Dansk Supermarked (a Danish supermarket chain) to discern a possible basis for cooperation. In Denmark, Dansk Supermarked would commission a translation to be absolutely sure what the letter says. The nine translators were asked to translate this letter. They were then asked to write down what they found most difficult while translating. The true purpose of the study was not explained to the translators, i.e., that culture-bound words were its primary concern.

Words and expressions either pointed out by the translators as being the most tricky, either shown to be problematic (as witnessed by unidiomatic, muddled or directly faulty translations or by the use of a number of microstrategies, especially paraphrases) were analysed. The translations and the translators' comments showed that the main terminological difficulties were in fact rooted in culture. In the following, some illustrative examples will be given and discussed, especially as to which way and to what extent they can be considered rooted in an English (or perhaps Anglo-American) culture. By necessity the comments refer to the Danish culture, but the aim is to show that the words in question are so culturally bound that they may present problems to the translator in any non-Anglo/American culture, even when translating within an international discourse community.

(1) The role of the retail outlet on the high street is evolving, driven by a shift in consumer buying behaviour.

(Excerpt from the source text)

Dictionaries define high street as "the main street of a town," i.e., what in Danish would be hovedgaden (litt.: the main street) in an almost direct translation. However, in a Denmark, the word hovedgaden is often used in a traffic context, which has prompted some of the translators to paraphrase and write about shops of a high street or about pedestrian streets to focus on the shopping theme of the text. The Danish terms hovedgaden and strøget or gågaden (alternative Danish words having the same meaning than the English term high street) often have the same denotation, but they have different connotations. The cultural challenge here is for the translator (whether 
Danish, Chinese or South American) to find out what a typical English high street really is and what its present role is in that particular society in order to be able to interpret the surrounding text.

(2) Continued expansion of the Multiple Grocers means that they are increasingly becoming a one-stop-shop for everyday purchases.

(Excerpt from the source text)

In this sentence, two expressions were identified as difficult. The name Multiple Grocers, whose referent was unclear, and one-stop-shop, which is discussed below. The translations of Multiple Grocers showed that it was hard to determine its meaning [the translators were intrigued by the (inexplicable) capital letters]. A definition of multiple grocers as such can hardly be found, but it is important to note that it contrasts with independent grocers: "The number of independent grocers has also fallen, while multiple grocer outlets have increased in number and average store size." Futhermore, the expression often collocates with Tesco, Sainsbury's, Safeways, etc. on the Internet. It seems that multiple grocers are simply a chain of grocers. Some nonEnglish members of the international discourse society of retailers may know the expression multiple grocers, but it could also be an English term which is not frequently used abroad. Conversely, the concept of a chain of grocers is of course well known.

At first glance one-stop-shop seems fairly self-explanatory, but what the translator/receiver actually understands may depend heavily on the cultural framework. For example, a parameter such as size is definitely not self-explanatory. The example reflects the classic translational problem typically illustrated by bread and its various translations. Bread is something well-known in all cultures. The word bread can readily be translated by an entirely equivalent name: pain, Brot, brød, but even though the basic characteristics of bread are present in all cases, the translations may in fact refer to quite different kinds of breads depending on the culture in question (Benjamin 1923/2000: 18).

(3) As a consequence, the high street is becoming a leisure destination for customers seeking more experiential shopping and more considered purchases.

(Excerpt from the source text)

Leisure destination as well as flagship destination (see below) turned out to be difficult to translate. As the individual words leisure and flagship are easy to look up in a Danish dictionary and would be part of the experienced translator's vocabulary, we assume that it is their combination with the word destination that causes trouble. The Latin-based word destination does exist in Danish and is primarily used as a physical place you travel to, often abroad on a package holiday. ${ }^{2}$ In English destination may mean the same as destination in Danish, but in some contexts and in combination with leisure it seems to have acquired the status of a cultural concept: a place you go to (not for a week, but for the day) in your spare time to amuse yourself strolling around, visiting shops, the cinema or a café. This meaning is borne out by the following quotes from websites:

(4) a. Scotland's favourite regional shopping centre offers a world-class retail and leisure destination. ${ }^{3}$

b. Bluewater - the most innovative and exciting shopping center and leisure destination in Europe today. ${ }^{4}$ 
The translators have typically tried various combinations involving some kind of outing, but the reality is that the phenomenon of a leisure destination as witnessed by the above definitions is not a well-known Danish concept.

(5) As a consequence, the high street is becoming a leisure destination for customers seeking more experiential shopping and more considered purchases.

(Excerpt from the source text)

The expression experiential shopping is constructed from two well-known words, but the concept seems very culturally-bound. Three of the nine translators had actually misunderstood / misread the expression and translated it into eksperimenterer med deres indkøb [that is, a situation where people experiment with their shopping] which may indicate that they are not familiar with the concept and have read it as experimental shopping. Experiental shopping is closely connected with the above concept of leisure destination as it is part of the same cultural trend to divide one's shopping into shopping for necessities in huge out-of-town one-stop-shops and to consider shopping for gifts and luxuries a pleasurable spare time activity which takes place in the high street or at a leisure destination. This trend is bolstered by the fact that English shops are now open on Sundays - something which is unthinkable in many countries.

(6) This goes hand in hand with developing our own stores to be flagship destinations for the company.

(Excerpt from the source text)

In the term company's flagship, flagship is used in a metaphorical sense. The corresponding term is very well-known in Denmark (flagskib). What has puzzled the translators is again the combination of flagship with destination; a direct translation into Danish sounds distinctly odd as the concept is not established in Denmark. The concept is related to a place where people go in their spare time to amuse themselves and the expression seems to interact with leisure destination such that flagship indicates major (company) activity, whereas the destination part of the expression focuses on the consumer and his experiences - again a cultural concept as witnessed by the following quotes from the Internet:

- As a recreation area for Cumbrians and visitors alike, it will be a flagship destination and will boost the image of West Cumbria as an area to live and work. ${ }^{5}$

- Situated in Guildford's High Street, the Angel is a small yet luxurious boutique hotel and a flagship destination in Guildford for Conferencing and Banqueting. ${ }^{6}$

The majority of difficult words and expressions in the Thorntons text are culturebound in the sense that Britain is often one step ahead of Denmark as regards new trends, and therefore new concepts - in this case within retailing. Many of the concepts which have become established in an English-speaking context are still unfamiliar to a Danish audience (even though Denmark is also a Western European country and physically close to England), unless of course the target group belongs to an intercultural discourse community of retailers in which case they may be familiar with the concepts, but to what extent? Two further hypotheses are generated by this small-scale study, namely:

1. that if you move outside the Western culture to, say, Asian, Indian, and African cultures, these concepts could be completely unknown, even within retailing, 
because of their close connections with an Anglo-American cultural framework, and;

2. that globalisation really means common in an Anglo-American context.

As seen from the above examples (and as shown by a large number of paraphrases in the target texts), the translators in the Thorntons case have not been able to rely on a cultura franca in the sense of definition 2. It may be that very specific discourse communities do share a number of common concepts, even when these concepts are without established names in languages other than English (e.g., a linguistic equivalent to one-stop-shop does not exist in Denmark), but if translation is required the translator is faced with a choice of potentially complicated paraphrases or a large number of borrowings to the detriment of the style and fluency of the target text which makes reliance on cultura franca even in the sense of definition 1 problematic for the translator.

On the basis of this small-scale study we conclude that globalisation does not really unburden the translator and that culture-bound words and concepts still pose a major challenge even to the experienced translator and even within international areas such as retailing. Globalisation may have eased the job somewhat, in the sense that more and more concepts become global, but people, even within specific discourse communities, are bound to interpret a text on the basis of their own cultural framework - they may know theoretically what a leisure destination means within retailing, but they may not have any real grasp of its role in a particular society. The receivers of a text will always superimpose their own cultural layer on their interpretation, i.e., global concepts will be interpreted in a local context:

As the sociologist Karl Otto Hondrich argues (1999), shared knowledge of an event is always supplemented by culture-specific background knowledge, presuppositions, and prejudices, resulting in different interpretations. In other words, everything which reaches an audience in some globalised way, is filtered, interpreted, and localised (Schäffner 1999: 96-97; Venuti 2000: 469 makes a similar point).

\section{Conclusion}

In this article we have discussed the translator's role as cultural mediator in an age where globalisation and the existence of a global village are increasingly taken for granted. We have argued that a cultura franca is not a natural consequence of a lingua franca and furthermore that a broad definition of culture makes it as important to the LSP as to the literary translator. Schäffner (1999: 96-97) asks: "When discursive practices and genres become identical worldwide, when people watch the same news, the same soap operas, does this establish a global culture?"

On the basis of the theoretical discussions and the empirical data of this article, the answer to Schäffner's question is definitely negative and in practice this view is also supported by the growing localisation industry. Even within a discourse community there is bound to be a certain dependence on one's own cultural background, unless the discourse community is very narrow. Words, expressions, and contexts may for instance be understood theoretically but not by experience. As touched upon in the Thorntons case there may be various levels of understanding of cultural phenomena also within a discourse community. Does the receiver know the concept in theory?, in practice? and does he have a name for it in his language? In connection 
with discourse societies, within which the LSP translator often works, it is furthermore difficult to distinguish the language belonging to that particular society from what can be termed ordinary language. The Thorntons case deals with the language of retailing, but it might also be interesting to look at non-specialist culture-bound words and expressions in a particular discourse community as they seem bound to create the same intercultural difficulties as in other non-specialist contexts. Even though various subcultures have indeed become globalised, cultural diversity is still so great in most walks of life that the cultural dimension of translating is as complicated and challenging as ever:

Translation never communicates in an untroubled fashion because the translator negotiates the linguistic and cultural differences of the foreign text by reducing them and supplying another set of differences, basically domestic, drawn from the receiving language and culture to enable the foreign to be received there (Venuti 2000: 468).

The translator continues to mediate and perhaps precisely because of globalisation and ever-increasing international business the role of the translator is very much that of a cultural mediator. When Snell-Hornby (1999: 111) claimed that "the European translator of today operates in a world that is globalised, hybridised and at the same time still characterised by intercultural differences," she was mainly thinking about the literary translator, but it seems that the LSP translator can safely be included.

\section{NOTES}

1. Confectionary Market Assessment (Updated last January 1999), visited 4 January 2010, <http:// www.researchandmarkets.com/reports/3572/>.

2. Det Danske Sprog- og Literaturselskab (2010): Korpus 2000, visited 10 March 2006, <http://korpus. dsl.dk/korpus2000/indgang.php>.

3. <http://www.capital-shopping-centres.co.uk/shoppingcentres/braehead/pdf/brochure.pdf $>$, visited 16 March 2006.

4. Bluewater Shopping Center (2010), visited 4 January 2010, <http://www.studios92.com/guide/bluewater.htm>.

5. Cumbria County Council (2003): County Council News - Spring 2003, visited 4 January 2010, $<$ http://www.cumbria.gov.uk/newspapers/paper0303/ticket.htm>.

6. Guilford Borough Council (Updated last 24 August 2009): Angel Posting House, visited 4 January 2010, <http://www.guildford.gov.uk/GuildfordWeb/Business/Meetings/Venues/>.

\section{REFERENCES}

Al-DabBagh, Abdulla (2005): Globalism and the universal language. English Today 82. 21(2):312.

AlPtekin, Cem (2002): Towards intercultural communicative competence in ELT. ELT Journal. 56(1):57-64.

Askehave, Inger and Norlyk, Birgitte, eds. (2006): Meanings and Messages. Arhus: Academia.

Bassnett, Susan and Lefevere, André, eds. (1990): Translation, History and Culture. London/ New York: Pinter.

Benjamin, Walter (1923/2000): The task of the translator. In: Lawrence Venuti, ed. The Translation Studies Reader. London: Routledge, 15-25.

Crystal, David (2003): English as a Global Language. Cambridge: CUP.

Dam, Helle V. and Zethsen, Karen Korning (2008): Translator status: A study of Danish company translators. Translator. 14(1):71-96. 
Dam, Helle V. and Zethsen, Karen Korning (2009): Who said low status?: A study on factors affecting the perception of translator status. Journal of Specialised Translation. 12: 2-36.

Dam, Helle V. and Zethsen, Karen Korning (forthcoming Meta): The status of professional business translators on the Danish market: A Comparative Study of Company, Agency and Freelance Translators.

Dam, Helle V. and Zethsen, Karen Korning (forthcoming): Translator status - helpers and opponents in the ongoing battle of an emerging profession.

Geertz, Clifford (1973): The Interpretation of Cultures. New York: Basic Books.

Hall, Edward T. (1983/1989): The Dance of Life. New York: Doubleday.

Hofstede, Geert (1991/2005): Cultures and Organizations - Software of the Mind. London: McGraw-Hill.

Katan, David (1999): Translating Cultures. An introduction for Translators, Interpreters and Mediators. Manchester: St. Jerome.

Kirkness, Alan (1997): Eurolatin and English today. English Today 49. 13(1):3-8.

McKAY, Sandra Lee (2000): Teaching English as an International Language: Implications for cultural materials in the classroom. TESOL Journal. 9(4):7-11.

Nedergaard-Larsen, Birgit (1993): Culture-bound problems in subtitling. Perspectives: Studies in Translatology. 1(2):207-241.

ReIss, Katarina and Vermeer, Hans (1984): Grundlegung einer allgemeinen Translationstheorie. Tübingen: Max Niemeyer.

Schäffner, Christina (1999): Globalisation, Communication, Translation. Current Issues in Language and Society. 6(2):93-102.

SNelL-Hornby, Mary (1999): Communicating in the Global Village: On Language, Translation and Cultural Identity. Current Issues in Language and Society. 6(2):103-120.

Snell-Hornby (2006): The Turns of Translation Studies. Amsterdam: John Benjamins.

Swales, John M. (1990): Genre Analysis: English in academic and research settings. Cambridge: CUP.

TyLoR, Edward B. (1871/1924): Primitive Culture. New York: Brentano's.

Tүмосzко, Maria (2003): Ideology and the position of the translator: In what sense is a translator 'in-between'? In: María Calzada Pérez, ed. Apropos of Ideology. Translation Studies on Ideology - Ideologies in Translation Studies. Manchester: St. Jerome, 181-201.

Vermeer, Hans (1989/2000): Skopos and commission in translational action. (Translated by Andrew Chesterman) In: Lawrence Venuti, ed. The Translation Studies Reader. London: Routledge, 121-232.

Vermeer, Hans (1992): Is translation a linguistic or a cultural process? In: Malcolm Coulthard, ed. Studies in Translation/Estudos in Traducao. Ilha do Desterro. Florianopolis: Edufsc, 37-49.

Venuti, Lawrence (2000): The Translation Studies Reader. London: Routledge.

Zethsen, Karen Korning (2006): The Translator as Cultural Mediator. In: Inger Askehave and Birgitte Norly K, eds. Meanings and Messages. Arhus: Academia, 97-114. 